Canadian Science Publishing
Machoum

Canadian Journal of Earth Sciences Revue canadienne des sciences de la Terre

\title{
Lesleya Lesquereux from the Pennsylvanian of the Iberian Massif: part of a dryland megaflora from the Variscan orogen, northwestern Portugal
}

\begin{tabular}{|r|l|}
\hline Journal: & Canadian Journal of Earth Sciences \\
\hline Manuscript ID & cjes-2015-0213.R2 \\
\hline Manuscript Type: & Article \\
\hline Complete List of Authors: & $\begin{array}{l}\text { Correia, Pedro; Geology Centre of the University of Porto (CGUP) } \\
\text { Sá, Artur; Department of Geology, University of Trás-os-Montes e Alto } \\
\text { Douro } \\
\text { Murphy, J. Brendan; Department of Earth Sciences, St. Francis Xavier } \\
\text { University } \\
\text { Simunek, Zbynĕk; Czech Geological Survey } \\
\text { Flores, Deolinda; Geology Centre of the University of Porto }\end{array}$ \\
\hline Keyword: & \begin{tabular}{l} 
Lesleya, megaflora, Iberian Massif, drylands, riparian environments \\
\hline
\end{tabular} \\
\hline
\end{tabular}

\section{SCHOLARONE}

Manuscripts 


\section{Lesleya Lesquereux from the Pennsylvanian of the Iberian Massif: part of a}

2 dryland megaflora from the Variscan orogen, northwestern Portugal

3 Pedro Correia ${ }^{1 *}$, Artur A. Sá ${ }^{2,3}$, J. Brendan Murphy ${ }^{4}$, Zbyněk Šimůnek ${ }^{5}$ and Deolinda

$4 \quad$ Flores ${ }^{1,6}$

5

$6{ }^{1}$ Institute of Earth Sciences, Pole of the Faculty of Sciences, University of Porto, Rua do

$7 \quad$ Campo Alegre, 687, 4169-007 Porto, Portugal; pedro.correia@,fc.up.pt

$8 \quad{ }^{2}$ Department of Geology, University of Trás-os-Montes e Alto Douro, 5001-801 Vila

$9 \quad$ Real, Portugal; asa@utad.pt

$10{ }^{3}$ Geosciences Center, University of Coimbra, Pólo II, 3030-790 Coimbra, Portugal.

$11{ }^{4}$ Department of Earth Sciences, St. Francis Xavier University, Antigonish, Nova Scotia,

12 B2G W5, Canada; bmurphy@,stfx.ca

$13{ }^{5}$ Czech Geological Survey, Klárov 3/131, 11821 Praha 1, Czech Republic;

14 zbynek.simunek@geology.cz

$15{ }^{6}$ Department of Geosciences, Environmental and Spatial Planning, Faculty of Sciences

16 of University of Porto, Rua do Campo Alegre, 687, 4169-007 Porto, Portugal;

17 dflores@fc.up.pt

* Corresponding author 


\section{ABSTRACT}

26 The Carboniferous-early Permian plant genus Lesleya is a characteristic component of

27 'dryland floras' that occupied a wide range of moisture-stressed, well-drained environments in tropical regions of Euramerica. Fossil records of Lesleya are almost exclusively found in basinal lowlands. For example, occurrences in Early Pennsylvanian-age, seasonally-dry, parautochthonous deposits in basinal lowlands of North America (e.g., Illinois Basin, USA), indicate that Lesleya lived in that region in low altitude (lowland) paleoenvironments during dry climatic intervals. In this paper, we document the first occurrence of Lesleya during the Carboniferous on the Iberian Massif, in lower Gzhelian (Upper Pennsylvanian) strata of the Douro Carboniferous Basin, in northwestern Portugal. This newly discovered occurrence includes a new species, Lesleya iberiensis sp. nov., recognized on the basis of natural molds of leaves. The Portuguese Lesleya fossils are from upland intramontane deposits and they occur between coal-beds. Their fossil remains are preserved in mica-rich shales which were deposited between sandstone-dominated fluvial and shale-dominated lacustrine deposits, suggesting that this megaflora was deposited near freshwater bodies. These new data provide evidence that this megaflora grew in mountain riparian environments within the Variscan orogen, either in localized, well-drained areas or during drier climatic intervals in the Late Pennsylvanian.

Keywords: Lesleya; megaflora; Iberian Massif; Variscan orogen; drylands; riparian environments; intramontane basins. 


\section{Introduction}

51

Pennsylvanian-age 'dryland floras' include a diversity of terrestrial plants that occupied a wide range of moisture-deficient and well-drained environments within the Euramerican Floristic Province (here called Euramerica) (e.g., Falcon-Lang 2003; DiMichele et al. 2009, 2010; Falcon-Lang et al. 2009, 2011a,b; Bashforth et al. 2014). These dryland floras flourished wherever favorable climatic and edaphic conditions existed, particularly where habitats became dry enough to support such biomes during dry climate intervals (e.g., DiMichele et al. 2009, 2010; Falcon-Lang et al. 2011b; van Hoof et al. 2013; Bashforth et al. 2014). Pennsylvanian-age dryland plant communities are still poorly understood compared to biomes that colonized tropical wetland ecosystems (Falcon-Lang 2003; Falcon-Lang et al. 2011a). Fossil records for dryland plant communities are almost exclusively found in basinal lowlands (e.g., Leary and Pfefferkorn 1977; Leary and Trask 1985; DiMichele et al. 2009, 2010; Falcon-Lang et al. 2009; Bashforth et al. 2014).

Lesleya is an enigmatic member of 'dryland (xerophilous-mesophilous) floras' (generally xeromorphic) and is one of the indicator taxa used to assess soil dryness conditions in Pennsylvanian-age deposits (e.g., DiMichele et al. 2010; Falcon-Lang et al. 2011a; Bashforth et al. 2014). Fossils of Lesleya are mainly found in seasonally-dry basinal lowlands (e.g., Leary and Pfefferkorn 1977; Leary and Trask 1985; DiMichele et al. 2008, 2010; Falcon-Lang et al. 2011a; Bashforth et al. 2014). In North America, paleoecological studies on Pennsylvanian-age parautochthonous deposits have examined seasonally-dry floral assemblages containing conifers, cordaitaleans, and pteridosperms including foliage of Lesleya (e.g., Leary and Pfefferkorn 1977; Leary and Trask 1985; Plotnick et al. 2008, 2009; DiMichele et al. 2010). These floral 
assemblages occur in basin-margin settings developed on drought-prone limestone substrates in basinal lowlands and are preserved in clastic rocks deposited between coalbeds (e.g., Plotnick et al. 2008, 2009; DiMichele et al. 2008, 2010). Lesleya is restricted to the equatorial regions of Euramerica, where it occurs in Carboniferous and lower Permian strata (e.g., Sellards 1908; Leary and Pfefferkorn 1977; Leary 1981; Wagner 2004; Leary and Trask 1985; Šimůnek 1996; Cleal and Thomas 2004; DiMichele et al. 2008, 2010). The megaflora containing Lesleya is limited to lower Bashkirian (Lower Pennsylvanian) strata in North America (e.g., Illinois Basin, USA), but it has a wider paleogeographical distribution in Carboniferous-lower Permian strata of Europe (e.g., Leary and Pfefferkorn 1977; Leary and Trask 1985; Šimůnek 1996; DiMichele et al. 2008, 2010).

\section{In this paper, we document the first occurrence of Lesleya in the Iberian Massif, on} the basis of leaf fossils recently found in lower Gzhelian (Upper Pennsylvanian) strata of the Douro Carboniferous Basin (DCB), in northwestern Portugal (Fig. 1). The DCB is an intramontane basin located adjacent to the Valongo Anticline in the Central Iberian Zone of the Variscan orogen (e.g., Wagner 1983; Domingos et al. 1983; Correia et al. 2013). The development of intramontane basins such as the DCB was common during the Variscan orogen (e.g., Wagner 2004; Cleal 2008; Wagner and Álvarez-Vázquez 2010; Bashforth et al. 2011) and such basins are well-documented in the Iberian Massif (e.g., Wagner 1983; Pinto de Jesus 2001). While recognizing that our results do not preclude the occurrence of Lesleya in a wide range of moisture-stressed environments, in this paper we provide a better understanding of the 'dryland floras' in the Iberian Massif, and we assess its significance for interpreting the paleoclimate, paleoecology and paleoenvironment in that region during the Late Pennsylvanian. 


\section{Geological background}

101

102 Geographical and geologic setting

103 The DCB (Fig. 1) occurs within the Douro-Beiras Carboniferous Trough (DBT),

which is located within the Central Iberian Zone, in the Iberian Massif of northwestern

Portugal. The DBT strikes northwest-southeast, and is $85 \mathrm{~km}$ in length with a width of

less than 1 km (e.g., Lemos de Sousa and Wagner 1983a; Pinto de Jesus 2001, 2003).

Within the DBT, there are several outcrops containing well-documented continental

Carboniferous strata, with ages ranging from Westphalian (Bolsovian-Asturian,

Moscovian, Middle Pennsylvanian) to Stephanian C (early Gzhelian, Late

110

Pennsylvanian). The DBT is generally interpreted as a pull-apart basin with a sinistral

strike-slip component (e.g., Pinto de Jesus 2001, 2003).

The basal strata of the DCB unconformably overlie lower Cambrian rocks of the

Schist-Greywacke Complex. The upper strata of the DCB are cut by a reverse fault that placed lower-middle Paleozoic (Silurian-Devonian) formations of the Valongo

Anticline over strata of the DCB (e.g., Domingos et al. 1983; Lemos de Sousa 1984;

116 Wagner et al. 1984; Pinto de Jesus 2001, 2003).

\section{Tectono-sedimentary units and depositional environments}

119 The stratigraphic and sedimentological sequence of the DCB is comprised, from the base to the top, of eight tectono-sedimentary units (TSU), some of which are related by lateral facies variations (Fig. 2A). TSU units A2, B2, C2 and D2 represent the lateral

122 facies variations of TSU units A1, B1, C1 and D1, respectively (Pinto de Jesus 2001, 123 2003; Fig. 2A). The following descriptions are summarized from Pinto de Jesus (2001, 2003). 
The basalmost unit, TSU A1, consists of alluvial fan debris characterized by flow-

126

127

128

129

130 dominated clastic rocks composed of red-brown or dark grey basal breccia deposits.

These deposits include interbedded polymictic conglomerates, generally with a massive, matrix-supported texture and, more rarely, with clast-supported texture lacking welldefined internal sedimentary structures. Clasts are angular and range from silt to boulder (up to 2 meters) in size. Clast lithologies are very variable (shale, greywacke, granite, greisen, gneiss, mica-schist, conglomerate and quartzite) and likely resulted from the erosion of adjacent mountainous regions such as the Valongo Anticline and surrounding areas underlain by the Schist-Greywacke Complex. The basal breccia varies from meters to decameters in thickness. The top of the basal breccia is composed of dark grey to black mudstones, with small angular quartz clasts.

TSU B1 contains phytogenic and siliciclastic deposits that occur along the base of the DCB, and consist of alternating strata of shale, sandstone and coal beds. The shale strata display parallel lamination, along which the fossil plants occur. The fossiliferous strata preserve a highly diverse macroflora. At the top of the TSU B1 sequence, the phytogenic and siliciclastic strata are overlain by fluvial deposits.

TSU C1 is dominated by fluvial deposits with well-defined erosive lower contacts that cut the underlying strata, including the phytogenic and siliciclastic deposits. These deposits represent a fluvial system complex with vertical accretion composed of interbedded conglomerates, sandstones and siltstones, with pelitic layers more prevalent near the top of the sequence.

TSU D1 consists of phytogenic and siliciclastic deposits that occur at the top of the DCB sequence. They were deposited above the fluvial sequences of TSU C1, are very fossiliferous, and consist of alternating beds of coal, siltstone, mudstone and conglomerate. The more pelitic lithofacies generally display either a parallel internal 
150 lamination or a more massive texture. These sequences may also contain rare lenticular

151 bodies composed of conglomerate or coarse sandstone.

152 TSU A2 is characterized by deposits of intra-Carboniferous breccia that are in fault 153 contact (a reverse fault) with older Carboniferous and Silurian strata within the DCB.

154 Most of the breccia deposits exhibit a clast-supported texture, although a matrix-

155 supported texture is observed locally. The breccia consists of clasts of quartzite, shale,

156 quartz and more rarely sandstone in a silty-clay matrix. Clasts can range up to $30 \mathrm{~cm}$ in

157 length and typically are subangular to subrounded. The deposits vary in thickness from

158 a few meters to about 50 meters.

159 TSU B2 consists of phytogenic and siliciclastic deposits of the base of the DCB.

160 Their characteristics are very similar to the observed in the TSU B1.

161 TSU C2 is dominated by fluvial deposits, whose structure and composition are very 162 similar to that of TSU C1.

163 TSU D2 consists of phytogenic and siliciclastic strata that are the youngest deposits 164 preserved in the DCB and have a stratigraphy similar to that of TSU D1. 2003).

173 In previous studies of the DCB fossil megaflora, Lemos de Sousa and Wagner 174 (1983b) emphasized the occurrence of Pseudomariopteris cf. busquetii (Zeiller) Danzé- 
175 Corsin, cf. Taeniopteris multinervia Weiss and Neuropteris ovata Hoffmann var.

176 pseudovata Gothan and Sze. Those author's interpretations of the paleoenvironmental,

177 paleoecological and paleogeographic conditions for the DCB strata were based on the

178 strata being adjacent to mountainous regions, such as Valongo Anticline, and on the

179 occurrence of dryland (xerophilous-mesophilous) floras in the Iberian Massif. Previous

180 descriptions of the DCB dryland floras also identified the conifers Ernestiodendron

181 filiciforme (Von Schlotheim pars) Florin, cf. Culmitzschia frondosa (Renault) var.

182 zeilleri (Florin) Clement-Westerhof and Culmitzschia parvifolia (Florin) Clement-

183 Westerhof and the cordaitales Dicranophyllum gallicum Grand'Eury and

184 Dicranophyllum lusitanicum (Heer) Lima (Wagner 1983; Wagner and Lemos de Sousa

185 1983; Domingos et al. 1983).

186 In addition to these floras, paleozoological studies (Eagar 1983) documented

187 occurrences of the non-marine bivalves Anthraconaia lusitanica Teixeira and

188 Anthraconaia (?) altissima Eagar in the DCB. These bivalves indicate freshwater

189 conditions, which are common in intramontane limnic basins (e.g., Eagar 1983, 1987;

190 Eagar and Belt 2003; Pleijel et al. 2004; Racheboeuf et al. 2002, 2008; Charbonnier et

191 al. 2008; Schultze 2009; Tibert et al. 2011).

192

193 Material and methods

194

195

The Lesleya fossils reported herein are natural molds of leaves collected from

recently discovered, early Gzhelian-age (Late Pennsylvanian) outcrops in the DCB,

197 located within the São Pedro da Cova region of northwestern Portugal (Fig. 1; outcrop

198 location: $41^{\circ} 09^{\prime} 42.56^{\prime \prime} \mathrm{N}$; $\left.08^{\circ} 30^{\prime} 14.68^{\prime \prime} \mathrm{W}\right)$. These outcrops correspond to the upper

199 part of TSU B2 in transition to TSU C2 of the DCB stratigraphy (Fig. 2A). The Lesleya 
200 fossils occur at various stratigraphic levels, within compressed grey shales that are 201 interbedded with sandstone deposits of variable thickness (Figs. 2B and 3). The grey

202 shales are composed of two distinct lithofacies: mica-rich shales that contain abundant 203 detrital muscovite and clay-rich shales with more pelitic features. Both lithofacies are 204 reasonably well exposed and contain a variety of fossils: the mica-rich shales contain various megafloral elements (e.g. Lesleya and Cordaites), whereas the clay-rich shales contain non-marine bivalves (Anthraconaia) and insects (blattodeans) (Figs. 2B and 3).

The Lesleya leaves were found in association with leaves of Cordaites. An associated flora, consisting of species such as Neuropteris ovata ?var. pseudovata Gothan and Sze, Linopteris neuropteroides (Gutbier) Potonié, Dicksonites plukenetii (Sternberg) Sterzel, Pecopteris cyathea (Von Schlotheim) Brongniart, Pseudomariopteris cordato-ovata (Weiss) Gillespie et al. ex Krings and Kerp, Sphenophyllum oblongifolium (Germar and Kaulfuss) Unger, Calamites suckowii Brongniart, Callipteridium (Eucallipteridium) gigas (Gutbier) Weiss, Acitheca polymorpha (Brongniart) Schimper and Asterophyllites equisetiformis (Von Schlotheim) Brongniart. This fossil plant assemblage occurs in association with lacustrine deposits containing non-marine bivalves that are probably Anthraconaia lusitanica Teixeira (Figs. 2B and 3).

The associated flora and fauna were previously identified and described by Wagner $(1983,1984)$ and Eagar (1983) in lower Gzhelian strata of the Iberian Massif and in the DCB (Wagner 1983; Eagar 1983; Lemos de Sousa and Wagner 1983a, b, 1985a, $b$; Wagner and Lemos de Sousa 1983).

Our report of Lesleya in the DCB is founded on four natural molds of leaves. The fossils were carefully cleaned either manually or mechanically with a vibro-tool. To help interpret its original structure, a latex cast (i.e., a positive replica) was made of the holotype. In order to preserve the integrity of the original specimen, its surface was 
coated with Paraloid B-72 dissolved in a dilute acetone solution before the latex was applied. Before being photographed, the latex cast was coated with magnesium oxide to enhance details. The holotype is stored in the Museum of Natural History and Science of the University of the Porto (UP-MHNFCP), Porto, Portugal. The three paratypes are stored in the Czech Geological Survey (ZS), Prague, Czech Republic.

\section{Systematic paleontology}

\section{Division Gymnospermophyta}

Class Pteridospermopsida Oliver and Scott, 1904

(or Class Cycadopsida Brongniart, 1843)

Order and Family unknown

Genus Lesleya Lesquereux, 1880

Remarks: Lesleya is restricted to equatorial regions of Euramerica where it ranges from the Carboniferous to early Permian (Table 1, Fig. 4). The geographic distribution of Lesleya is more widespread in Europe, where occurs mainly in Upper Pennsylvanian and lower Permian strata. In North America, Lesleya is found mainly in Lower Pennsylvanian strata, but some occurrences in lower Permian deposits have been documented (e.g., Leary and Pfefferkorn 1977; Leary and Trask 1985; Šimůnek 1996; DiMichele et al. 2008, 2010).

$$
\text { Lesleya contains } 11 \text { previously described species (e.g., Šimůnek 1996; Fig. 4, Table }
$$
1). Most species were established on the basis of fragmentary material (e.g., Lesquereux 1879 [atlas: pl. 25, figs. 1-3], 1884; Zeiller 1890; Remy and Remy 1975, 1978). Species are differentiated mainly on the basis of leaf characters (see Table 1), such as: leaf shape 
250 including type of apex and base shape; type of margin (e.g., entire or undulate margin);

251 and venation pattern, including type of venation (e.g., simple/pinnate or dichotomous;

252 curved or sinuous), number of lateral veins per $\mathrm{cm}$ on margin, and angles between

253 midvein/lateral vein and lateral vein/margin (e.g., Leary and Pfefferkorn 1977; Leary

254 1980; Šimůnek 1996). Where organically preserved material is available, cuticular

255 features also are useful for differentiating species of Lesleya and assessing their

256 phylogenetic relationships (e.g., Florin 1933; Šimůnek 1996). Here, we describe a new

257 species of Lesleya recognized on the basis of leaf fossils from lower Gzhelian (Upper

258 Pennsylvanian) deposits in Portugal. The new Portuguese species is most similar to

259 Lesleya cheimarosa, a geologically older congener described by Leary and Pfefferkorn

260 (1977) from lower Bashkirian (Lower Pennsylvanian) deposits in the Illinois Basin,

261 USA, and known by very complete leaf specimens, including the holotype (see Leary

262 and Pfefferkorn 1977, pl. 8, figs. 1, 2; Leary and Trask 1985, pl. 1, fig. 2).

263 The higher level affinities of Lesleya are uncertain. Its familial and ordinal affinities

264 are unknown (e.g., Taylor et al. 2009), whereas at the class level Lesleya variously has

265 been assigned to, or allied with, both the Cycadopsida and Pteridospermopsida (Remy

266 and Remy 1977, 1978; Leary 1990). A relationship between Lesleya and Permian-

267 Mesozoic cycads has been suggested on the basis of their similar foliage (e.g., Florin

268 1933; Remy and Remy 1978; Leary 1990, 1993, 1998; Wagner 2004; Taylor et al.

269 2009). Lesleya also has been suggested as a probable ancestor to cycads (Remy and

270 Remy 1978; Leary 1990; Taylor et al. 2009). Florin (1933) regarded Lesleya as a

271 primitive gymnosperm, however, it is not closely related to Permian seed ferns or

272 Mesozoic gymnosperms based on morphological and epidermal features. In addition,

273 Wagner (2004) proposed Lesleya as the tropical ancestor of the south temperate,

274 Permian Glossopteris Brongniart. That ancestral affinity seems unlikely considering 
275 differences between the two groups in their venation patterns (anastomosed/reticulated

276 venation in Glossopteris versus pinnatifid/pinnate venation in Lesleya) and reproductive

277 organs (e.g., Leary 1990, 1993, 1998).

278

279

Lesleya iberiensis sp. nov.

280

(Figs. 5 and 6)

281

282

Etymology: The specific epithet refers to the discovery of this species in the Iberian Massif.

Holotype: Natural mold of a nearly complete, large leaf broken in three pieces (separately numbered as UP-MHNFCP-094951/-094952/-094954) and preserved in grey shales (Fig. 5).

Paratypes: The three paratypes also are natural molds of leaves preserved in grey 324 shales (Fig. 6): ZS 507 and ZS 508 are the lower parts of two different leaves, whereas ZS 510 is a nearly complete, but poorly preserved leaf.

Type locality: Outcrops located in DCB, São Pedro da Cova region, northwestern Portugal (Fig. 1).

Type horizon and age: Compressed dark grey, mica-rich shale lithofacies; TSU B2 (Figs. 2B and 3). Early Gzhelian or Late Pennsylvanian in age.

Diagnosis: Simple leaves, maximum dimensions about $225 \mathrm{~mm}$ long and $50 \mathrm{~mm}$ wide; margins strongly arched towards the leaf base; base long and narrow (cuneate); margin entire; midvein broad, 1.0 to $3.0 \mathrm{~mm}$ wide; lateral veins fork once or twice; lateral veins oblique, slightly curved (arched) with a $7^{\circ}$ to $15^{\circ}$ angle at the midvein and $5^{\circ}$ to $35^{\circ}$ angle on margin; 10-13 veins per $\mathrm{cm}$ on margin. See Table 1 for more detailed comparisons with other named congeners. 
300 Description: The holotype (Fig. 5) is a nearly complete leaf missing its tip and an

301 irregular portion midway along its length. The leaf has a maximum width of $50 \mathrm{~mm}$ and

302 its preserved length is $225 \mathrm{~mm}$; when intact, its total length would have been about 250

$303 \mathrm{~mm}$. The lateral veins are widely spaced (11-13 veins per $\mathrm{cm}$ on margin) and fork once

304 or twice. They are oblique, slightly curved or arched from the midvein to the margin

305 and, as measured along the mid-length of the leaf, form angles of $7^{\circ}$ to $15^{\circ}$ with the

306 midvein and $30^{\circ}$ to $35^{\circ}$ with the margin. The midvein is broad (1.0-2.5 mm wide) and

307 bears several longitudinal striations. The paratypes ZS 507a, b (Fig. 6A, B) and ZS 508

308 (Fig. 6D) are lower parts of two leaves, with preserved dimensions of $100 \mathrm{~mm}$ long and

$30944 \mathrm{~mm}$ wide for ZS 507 and $70 \mathrm{~mm}$ long and $23 \mathrm{~mm}$ wide for ZS 508. In both

310 specimens, the lateral veins are oblique, curved from the midvein to the margin, spaced

$311 \quad 10-12$ veins per $\mathrm{cm}$ on margin and fork once or twice, forming angles of $9^{\circ}$ to $14^{\circ}$ with

312 the midvein and $5^{\circ}$ to $18^{\circ}$ with the margin. The midveins are $1-3 \mathrm{~mm}$ wide. The third

313 paratype, ZS 510 (Fig. 6C), is a nearly complete, but poorly preserved leaf, $>170 \mathrm{~mm}$

314 long and $44 \mathrm{~mm}$ wide. The lateral veins are oblique, slightly curved from the midvein to

315 the margin, spaced 10-12 veins per $\mathrm{cm}$ on margin and fork once or twice, forming

316 angles of $8^{\circ}-12^{\circ}$ with the midvein, and $16^{\circ}-27^{\circ}$ with the margin. The midveins are $2-3$

317 mm wide.

318 All four examples of Lesleya iberiensis sp. nov. display strongly arched margins with

319 a narrowing at the leaf base (i.e., cuneate-shaped leaf base; see different types of leaf

320 bases in Hickey 1977: appendix fig. 4), a long base, and a broad midvein that increases

321 in width towards the leaf base and is longitudinally striated. Although the apex is

322 missing from all four specimens, we restore it as having a lanceolate outline (see

323 reconstruction drawing of holotype in Fig. 5C). 
324 Remarks and comparisons: The Portuguese material displays morphological features

325 typical of the genus Lesleya. According to the original generic diagnosis from

326 Lesquereux (1880, p. 142), Lesleya is characterized by the following combination of

327 features: "Pinnae simple, very entire, sublanceolate, gradually narrowing towards the

328 base, traversed by a thick costa effaced under the apex; veins oblique, curved, equal,

329 repeatedly dichotomous". Subsequent treatments by Leary and Pfefferkorn (1977) and

330 Leary and Trask (1985) described Lesleya foliage as simple, large and wide leaves,

331 generally $10 \mathrm{~cm}$ in width and with a length that can exceed $30 \mathrm{~cm}$ (although there also

332 are some smaller forms from the Czech Republic; e.g., Šimůnek 1996), having a

333 lanceolate/sublanceolate apex and arched margins with a narrowing at the well-

334 developed leaf base, a broad midvein, and oblique lateral veins that are curved, and

335 equally repeatedly dichotomous.

336 The Portuguese material also is comparable to Megalopteris (Dawson) Andrews,

337 1875. This is due to the fact that Megalopteris and Lesleya foliage look very similar,

338 especially when preserved in a fragmentary state. Lesquereux (1880, p. 142) stated:

339 "This genus [Lesleya] is related by some of its characters to Neuropteris and by its

340 nervation of its fine species especially to Megalopteris". Megalopteris and Lesleya both

341 have large and wide foliage, lanceolate/sublanceolate apexes and arched margins, a

342 broad midvein, and oblique lateral veins that are curved and equally repeatedly

343 dichotomous. Upper pinnules of Megalopteris fronds can display arched margins with a

344 narrowing at the pinnule base (e.g., Zeiller 1900, fig. 85) reminiscent of leaf bases in

345 Lesleya. Leary (1980, p. 30) characterized Megalopteris as follows: "Frond rugose,

346 rachis thick, striated, broadly winged, pinnae alternate, very oblique, acute at apex,

347 often an inch wide and six inches long, margin undulate; midrib disappearing before

348 reaching apex, veins numerous, very oblique, curved, forking thrice very obliquely". 
349 According to Leary (1980), Lesleya differs from Megalopteris in that Lesleya foliage

350 consists of simple leaves, whereas Megalopteris is a compound leaf or pinnae

351 comprised of three or more lobes or pinnules (see Leary and Pfefferkorn 1977, fig. 8;

352 pls. 6-8; Leary and Trask 1985, pl. 1; see also additional descriptions by Leary and

353 Pfefferkorn 1977 and Cross et al. 2005). Leary (1980, p. 30) also stated, “...when a

354 complete leaf or frond is preserved, or even a fragment sufficient to observe the division

355 into two or more lobes, generic separation is quite simple". The Iberian leaf fossils

356 reported herein are sufficiently intact to demonstrate the absence of any Megalopteris-

357 like division; that supports our assignment of these specimens to Lesleya. Florin (1933)

358 was able to distinguish stomata of two genera based on cuticular material. Cuticular

359 features are uninformative for establishing the generic identity of Lesleya iberiensis sp.

360 nov., because no organically preserved (cuticular) material is available.

361 Among the 11 previously described species in the genus, Lesleya cheimarosa Leary

362 and Pfefferkorn 1977 from the early Bashkirian (Early Pennsylvanian) of the Illinois

363 Basin, USA (see Leary and Pfefferkorn 1977, pl. 8, figs. 1, 2; Leary and Trask 1985, pl.

364 1, fig. 2) is most similar to Lesleya iberiensis sp. nov. Both species are known by very

365 complete leaves that have entire margins, are similar in size and shape (i.e., large and

366 wide leaves, have strongly arched margins that narrow towards a cuneate-shaped base)

367 and have dichotomous venation. The holotype leaf of L. cheimarosa was described by

368 Leary and Pfefferkorn (1977, p. 25) as follows: "Simple leaf of considerable size, about

$36920 \mathrm{~cm}$ long and $4 \mathrm{~cm}$ wide, lanceolate with acute to attenuate tip. Base long and narrow

370 (acuminate). Margin entire, venation pinnate, midrib thick, 0.7 to $2.0 \mathrm{~mm}$ wide; lateral

371 veins fork once or twice; lateral veins S-shaped with a $10^{\circ}$ to $20^{\circ}$ angle at the midvein,

$37230^{\circ}$ to $70^{\circ}$ angle in center, and $40^{\circ}$ to $70^{\circ}$ angle on margin; 24 to 36 veins per $\mathrm{cm}$ on

373 margin". Based on that description, L. iberiensis sp. nov. differs from L. cheimarosa in 
374 details of the lateral veins. Specifically, L. cheimarosa displays S-shaped (sinuous) and 375 numerous (24-36) lateral veins (see Leary and Pfefferkorn 1977, fig. 8C, F, pp. 22, 23;

376 pl. 6, fig. 5; pl. 8, figs. 1, 2; see also description of Leary 1980), whereas L. iberiensis

377 sp. nov. has lateral veins that are slightly curved and fewer in number (10-13) and more 378 widely spaced (see Table 1). More detailed comparisons among all 12 congeners are 379 presented in Table 1.

\section{Discussion}

\section{Living habitat, deposition and preservation of Lesleya in intramontane basins from} the Iberia Massif

In Lower Pennsylvanian rocks in the Illinois Basin, USA, Lesleya occurs in parautochthonous deposits in seasonally-dry, basinal lowlands (e.g., Plotnick et al. 2008, 2009; DiMichele et al. 2008, 2010). In that region, Lesleya lived in low altitude environments during intervals of relatively dry climate (e.g., DiMichele et al. 2008, 2009, 2010). In the Iberian Massif, the Late Pennsylvanian-age Lesleya described herein is preserved in immature shales that are in gradational contact with sandstone deposits (Figs. 2B and 3). These DCB strata represent deposition at more upland elevations and occur in areas adjacent to mountainous regions, such as the Valongo Anticline located in the Central Iberian of the Variscan orogen (e.g., Wagner 1983; Domingos et al. 1983; Correia et al. 2013). These strata previously have been shown to be syntectonic, siliciclastic, intramontane deposits resulting from the erosion of surrounding areas (e.g., Wagner 1983; Domingos et al. 1983; Pinto de Jesus 2001; Figs. 1 and 7). Moreover, the frequent and cyclic occurrence of sandstone deposits in the DCB (described as TSU $\mathrm{C} 1 / \mathrm{C} 2$ ), including those occurring between the Lesleya deposits within TSU B2 (Figs. 2 
399

400

401

402

403

404

405

406

407

408

409

410

411

412

413

414

415

416

417

418

419

420

421

422

and 3), indicate that this megaflora was associated with fluvial-dominated environments

(Figs. 1 and 7). This evidence indicates that Lesleya grew in riparian environments in mountainous regions within the Variscan orogen during the Late Pennsylvanian.

\section{Interpretation of the climate, vegetation ecology and lacustrine depositional environments in DCB}

In lower Bashkirian (Lower Pennsylvanian) strata of North America, Lesleya has been interpreted as part of a seasonally-dry (= dryland) flora (e.g., DiMichele et al. 2010; Falcon-Lang et al. 2011a; Bashforth et al. 2014). The Portuguese Lesleya outcrops occur between coal-bed strata in TSU B2 (Fig. 2A). The presence of Lesleya in discrete horizons in the Iberian Massif may indicate those plants were growing in localized, drier or well-drained conditions. An alternative interpretation to this scenario is that deposition and preservation of Lesleya and possibly other components of the associated flora in the DCB occurred during intervals of drier and less humid climate within the region.

$$
\text { In the Portuguese outcrops that contain Lesleya, the abundance of }
$$

pteridosperms/ferns (the most common genera are Pecopteris, Sphenopteris and Callipteridium) and coniferopsids (e.g., Cordaites) indicates that the latter taxonomic groups dominated the resident floral assemblages. Other groups, such as sphenopsids (e.g., Sphenophyllum, Calamites and Asterophyllites) occur less frequently, although they are locally common in the DCB strata, whereas lycopsids and Lesleya are very rare. The conifers Ernestiodendron and Culmitzschia and the cordaitale Dicranophyllum have not been documented in the new Lesleya outcrops, but they occur commonly in the DCB, in particularly in São Pedro da Cova region. 
The Lesleya deposits are interlayered with lacustrine deposits rich in Anthraconaia-

424 like non-marine (limnic) bivalves, which suggests the associated megaflora grew in or adjacent to marginal lacustrine environments.

426

\section{Conclusions}

In this paper, we document the first occurrence of Lesleya within the Iberian Massif of northwestern Portugal. We also describe a new Late Pennsylvanian species, Lesleya iberiensis sp. nov., on the basis of leaf impressions. Similarities in leaf structures noted for L. iberiensis sp. nov. and L. cheimarosa (Early Pennsylvanian, USA) may indicate a close relationship between the two congeners, perhaps with the younger L. iberiensis sp. nov. having descended from the older L. cheimarosa lineage. Although a possible relationship between those congeners is intriguing, it remains conjecture pending a rigorous analysis of relationships within the genus. and well-drained environments within Euramerica. In North America, the occurrence of

446 Lesleya in Lower Pennsylvanian parautochthonous deposits in seasonally-dry basinal 447 lowlands of the Illinois Basin, USA, indicates Lesleya grew there in low altitude 
448 (lowland) environments during dry climatic intervals (see e.g., DiMichele et al. 2008, $4492009,2010)$. Our report of Lesleya in an intramontane basin within the Iberian Massif is 450 an example of this genus also living at higher elevations, where its preferred growing 451 conditions (i.e., seasonally dry and well drained) were present. Those conditions within 452 the Iberian Massif may have been localized or the result of longer term and more 453 widespread, dry climatic intervals in the region during the Late Pennsylvanian.

\section{Acknowledgements}

The authors are grateful to Dr. Richard Leary (Illinois State Museum, Springfield, USA) for help describing and classifying the new Lesleya species and for discussions about systematic paleontology, to the Czech Geological Survey (Prague) for laboratorial support and access to their libraries specialized in paleobotany, and to Dr. Arden R. Bashforth (Geological Museum, Natural History Museum of Denmark, University of Copenhagen) and Dr. Jim D. Gardner (Royal Tyrrell Museum of Palaeontology, Drumheller, Alberta, Canada) for their helpful comments on the submitted manuscript. This study was financially supported by Fundação Calouste Gulbenkian. Additional support was provided to P. Correia by a PhD scholarship (SFRH/BD/78741/2011) funded by Fundação da Ciência e Tecnologia (QREN-POPH-Type 4.1-Advanced

467 Training, with subsidies from European Social Fund and national funds MCTES), to Z. Šimůnek by the Grant agency of the Czech Republic (project no. GAP210/12/2053), and to J.B. Murphy by a Discovery Grant from the Natural Sciences and Engineering 470 Research Council of Canada.

\section{References}


473 Andrews, E.B. 1875. Description of fossil plants from the coal measures of Ohio.

$474 \quad$ Report of the Geological Survey of Ohio, 2: 414-425.

475 Bashforth, A.R., Opluštil, S., Drábková, J., Gibling, M.R., and Falcon-Lang, H.J. 2011.

476 Landscape gradients and patchiness in riparian vegetation on a Middle

477 Pennsylvanian braided-river plain prone to flood disturbance (Nýřany Member,

478 Central and Western Bohemian Basin, Czech Republic). Review of Palaeobotany

$479 \quad$ and Palynology, 163: 153-189.

480 Bashforth, A.R., Cleal, C.J., Gibling, M.R., Falcon-Lang, H.J., and Miller, R.F. 2014.

481 Paleoecology of Early Pennsylvanian vegetation on a seasonally dry tropical landscape (Tynemouth Creek Formation, New Brunswick, Canada). Review of Palaeobotany and Palynology, 200: 229-263.

484
Brongniart, M.A. 1843. Enumération des Genres de Plantes cultivés au Muséum d'Histoire Naturelle de Paris. Fortin, Masson et Cie, Libraries, Paris.

Charbonnier, S., Vannier, J., Galtier, J., Perrier, V., Chabard, D., and Sotty, D. 2008. Diversity and paleoenvironment of the flora from the nodules of the Montceau-lesMines biota (Late Carboniferous, France). Palaios, 23: 210-222.

Cleal, C.J. 2008. Palaeofloristics of Middle Pennsylvanian medullosaleans in Variscan Euramerica. Palaeogeography, Palaeoclimatology, Palaeoecology, 268: 164-180.

Cleal, C.J., and Thomas, B.A. 2004. Late Carboniferous palaeobotany of the upper Bideford Formation, north Devon: a coastal setting for a Coal Measures flora. Proceedings of the Geologists' Association, 115: 267-281.

Correia, P., Murphy, J.B., Sá, A., Domingos, R., and Flores, D. 2013. First Palaeozoic arachnid from Portugal and implications for Carboniferous palaeobiogeography. Geological Journal, 48: 101-107. 
497 Cross, A.T., Gillespie, W.H., and Taggart, R.E. 2005. Upper Paleozoic vascular plants.

498 In Fossils of Ohio. Edited by R.M. Feldmann and M. Hackathorn. Ohio Department

499 of Natural Resources, Division of Geological Survey Bulletin, 70, pp. 396-479.

500 De Stéfani, C. 1901. Flore carbonifere e permiane della Toscana. Pubblicazioni

501 Regionali di Istituto di Studi Superiori Pratici e di Perfezionamento. Tipografia G.

502 Carnesecchi e Figli, Firenze.

503 DiMichele, W.A., Kerp, H., Tabor, N.J., and Looy, C.V. 2008. The so-called

504 "Paleophytic-Mesophytic" transition in equatorial Pangea - Multiple biomes and

505 vegetational tracking of climate change through geological time. Palaeogeography,

506 Palaeoclimatology, Palaeoecology, 268: 152-163.

507 DiMichele, W.A., Montañez, I.P., Poulsen, C.J., and Tabor, N.J. 2009. Climate and

508 vegetational regime shifts in the late Paleozoic ice age earth. Geobiology, 7: 200-

509226.

510 DiMichele, W.A., Cecil, C.B., Montañez, I.P., and Falcon-Lang, H.J. 2010. Cyclic

511 changes in Pennsylvanian paleoclimate and effects on floristic dynamics in tropical

512 Pangaea. International Journal of Coal Geology, 83: 329-344.

513 Domingos, L.C.FG., Freire, J.L.S., Silva, F. Gomes, Gonçalves, F., Pereira, E., and

514 Ribeiro, A. 1983. The structure of the intramontane Upper Carboniferous basins in

515 Portugal. In The Carboniferous of Portugal. Edited by M.J. Lemos de Sousa and

516 J.T. Oliveira. Memórias dos Serviços Geológicos de Portugal, Lisboa, Vol. 29, pp.

$517 \quad 187-194$.

518 Eagar, R.M.C. 1983. The non-marine bivalve fauna of the Stephanian C of North

519 Portugal. In The Carboniferous of Portugal. Edited by M.J. Lemos de Sousa and

520 J.T. Oliveira. Memórias dos Serviços Geológicos de Portugal, Lisboa, Vol. 29, pp.

$521 \quad 179-185$. 
522 Eagar, R.M.C. 1987. The shape of the Upper Carboniferous non marine bivalve

523 Anthraconaia in relation to the organic carbon content of the host sediment.

524 Transactions of the Royal Society of Edinburgh Earth Sciences, 78: 177-195.

525 Eagar, R.M.C., and Belt, E.S. 2003. Succession, palaeoecology, evolution, and

526 speciation of Pennsylvanian non-marine bivalves, Northern Appalachian Basin,

527 USA. Geological Journal, 38: 109-143.

528 Einsele, G. 1992. Sedimentary basins. Evolution, facies and sediment budget. Springer-

$529 \quad$ Verlag, Berlin.

530 Falcon-Lang, H.J. 2003. Late Carboniferous dryland tropical vegetation in an alluvial

531 plain setting, Joggins, Nova Scotia, Canada. Palaios, 18: 197-211.

532 Falcon-Lang, H.J., Pendleton, J.L., and Wellman, C.H. 2011a. Dryland plant

533 communities in the Pennsylvanian (mid- to late Bolsovian) Winterbourne

534 Formation of Bristol, southern Britain: further evidence for taphonomic megabias.

535 Review of Palaeobotany and Palynology, 166: 268-285.

536 Falcon-Lang, H.J., Jud, N.A., Nelson, W.J., DiMichele, W.A., Chaney, D.S., and Lucas,

537 S.G. 2011 b. Pennsylvanian coniferopsid forests in sabkha facies reveal the nature of $538 \quad$ seasonal tropical biomes. Geology, 39: 371-374.

539 Falcon-Lang, H.J., Nelson, W.J., Elrick, S., Looy, C.V., Ames, P.R., and DiMichele, 540 W.A. 2009. Incised channel fills containing conifers indicate that seasonally dry 541 vegetation dominated Pennsylvanian tropical lowlands. Geology, 37: 923-926.

542 Florin, R. 1933. Zur Kenntnis der paläozoischen Pflanzengattungen Lesleya Lesquereux 543 und Megalopteris Dawson. Arkiv för Botanik, A25: 1-23.

544 Grand'Eury, C.F. 1877. Flore Carbonifère du Départment de la Loire et du Centre de la $545 \quad$ France. Prémiere Partie-Botanique. Imprimerie Nationale, Paris. 
546 Grand'Eury, C.F. 1890. Geologie et paléontologie du bassin houiller du Gard. Saint-

547 Étienne, Théolier et Cie, Saint-Étienne.

548 Halle, S.B. 2014. Ein Beitrag zur Morphologie von Taeniopteris eckardtii (KURTZE

549 1839) - ein Farnsamer aus dem mitteldeutschen Kupferschiefer (Ober-Perm). Band,

550 29: 45-60.

551 Hickey, L.J. 1977. Stratigraphy and paleobotany of the Golden Valley Formation (Early

552 Tertiary) of western North Dakota. Geological Society of America Memoirs, 150:

$553 \quad 1-296$.

554 Kurtze, G.A. 1839. Commentatio de petrefactis quae in schisto bituminoso

555 mansfeldensi reperiuntur. Eduardum Anton., Halae.

556 Leary, R.L. 1980. Reclassification of Megalopteris sp.? Arber (1904) from the culm

557 measures of northwest Devon as Lesleya sp. Review of Palaeobotany and

$558 \quad$ Palynology, 30: 27-32.

559 Leary, R.L. 1981. Early Pennsylvanian geology and paleobotany of the Rock Island

560 County, Illinois, area. Part 1: Geology. Illinois State Museum Reports of

561 Investigations, 37: 1-88.

562 Leary, R.L. 1990. Possible Early Pennsylvanian ancestor of the Cycadales. Science, 563 249: 1152-1154.

564 Leary, R.L. 1993. Comparation of the Early Pennsylvanian Euramerican fossil plant 565 Lesleya with the Permian Glossopteris of South America. In Comptes Rendus 12e

566 Congrès Carbonifère, Buenos Aires, 1993, Vol. 2, pp. 107-116.

567 Leary, R.L. 1998. Venation patterns in some early Glossopteris. Palaebotanist, 47: 16568 19. 
569 Leary, R.L., and Pfefferkorn, H.W. 1977. An Early Pennsylvanian flora with

570 Megalopteris and Noeggerathiales from west-central Illinois. Illinois State

571 Geological Survey Circular, 500: 1-77.

572 Leary, R.L., and Trask, C.B. 1985. Early Pennsylvanian paleotopography and

573 depositional environments, Rock Island County, Illinois. Illinois State Geological

$574 \quad$ Survey, Guidebook, 18: 1-42.

575 Lemos de Sousa, M.J. 1984. Carta geológica de Portugal na escala de 1/50 000. Notícia

576 Explicativa da folha 9-D - Penafiel. Aditamento relativo ao Carbonífero. Serviços

577 Geológicos de Portugal, Lisboa.

578 Lemos de Sousa, M.J., and Wagner, R.H. 1983a. General description of the terrestrial

579 Carboniferous basins in Portugal and history of investigations. In The

580 Carboniferous of Portugal. Edited by M.J. Lemos de Sousa and J.T. Oliveira.

581 Memórias dos Serviços Geológicos de Portugal, Lisboa, Vol. 29, pp. 117-126.

582 Lemos de Sousa, M.J., and Wagner, R.H. 1983b. Precisões sobre a flora fóssil do Couto

583 Mineiro do Pejão e da mina Paraduça nº 1 (Bacia Carbonífera do Douro). In

584 Contributions to the Carboniferous geology and palaeontology of the Iberian

585 Peninsula. Edited by M.J. Lemos de Sousa. Universidade do Porto, Faculdade de

586 Ciências, Mineralogia e Geologia, Porto, pp. 157-169.

587 Lemos de Sousa, M.J., and Wagner, R.H. 1985a. Annotated catalogue of the Bernardino

588 António Gomes fossil plant collection in Lisbon. In Papers on the Carboniferous of

589 the Iberian Peninsula (sedimentology, stratigraphy, palaeontology, tectonics and

590 geochronology). Edited by M.J. Lemos de Sousa and R.H. Wagner. Anais da

591 Faculdade de Ciências do Porto, Porto, Supplement 64, pp. 411-434.

592 Lemos de Sousa, M.J., and Wagner, R.H. 1985b. Papers on the Carboniferous of the

593 Iberian Peninsula (Sedimentology, Stratigraphy, Palaeontology, Tectonics and 
594 Geochronology). Anais da Faculdade de Ciências do Porto, Porto, Supplement 64 $595 \quad$ (1983), $498 \mathrm{pp}$

596 Lesquereux, L. 1879-1884. Description of the coal flora of the Carboniferous formation 597 in Pennsylvanian and throughout the United States. Second Geological Survey of 598 Pennsylvania, Report of Progress P. 1879, vol. 1. (Atlas 1879): 1-18 + 86 plates; 5991880 , vol. $1: 1-354 ; 1880$, vol. 2 : 355-694; 1884, vol. 3: 695-975.

600 Oliver, F.W., and Scott, D.H. 1904. On the structure of the Palaeozoic seed 601 Lagenostoma lonuixi, with a statement of the evidence upon which it is referred to 602 Lyginodendron. Philosophical Transactions of the Royal Society of London B, 197: $603 \quad 193-247$.

604 Pinto de Jesus, A. 2001. Génese e Evolução da Bacia Carbonífera do Douro 605 (Estefaniano C inferior, NW de Portugal); Um Modelo. PhD thesis, Geology 606 Department, The University of Porto, Porto.

607 Pinto de Jesus, A. 2003. Evolução sedimentar e tectónica da Bacia Carbonífera do 608 Douro (Estefaniano C inferior, NW de Portugal). Caderno do Laboratorio 609 Xeolóxico de Laxe Coruña, 28: 107-125. 610 Pleijel, F., Rouse, G.W., and Vannier, J. 2004. Carboniferous fireworms 611 (Amphinomida: Annelida), with a discussion of species taxa in palaeontology. 612 Invertebrate Systematics, 18: 693-700.

613 Plotnick, R.E., Kenig, F., Scott, A., and Glasspool, I. 2008. Stop 3: Central Quarry. 614 Exceptionally well-preserved paleokarst and Pennsylvanian cave fills. In Deglacial 615 history and paleoenvironments of northern Illinois. 54th Midwest Friends of the 616 Pleistocene Field Conference. Edited by B. Curry. Illinois State Geological Survey 617 Open File Report, 2008-1, pp. 79-87. 
618 Plotnick, R.E., Kenig, F., Scott, A., Glasspool, I., Eble, C.F., and Lang, W.J. 2009.

619 Pennsylvanian paleokarst and cave fills from northern Illinois, USA: a window into

620 late Carboniferous environments and landscapes. Palaios, 24: 627-637.

621 Racheboeuf, P.R, Vannier, J., and Anderson, L.I. 2002. A new three-dimensionally

622 preserved xiphosuran chelicerate from the Montceau-Les-Mines Lagerstätte

623 (Carboniferous, France). Palaeontology, 45: 125-147.

624 Racheboeuf, P.R., Vannier, J., Schram, F.R., Chabard, D., and Sotty, D. 2008. The

625 euthycarcinoid arthropods from Montceau-les-Mines, France: functional

626 morphology and affinities. Earth and Environmental Science Transactions of the

627 Royal Society of Edinburgh, 99: 11-25.

628 Remy, W., and Remy, R. 1975. Lesleya weilerbachensis n. sp. aus dem höheren Westfal

629 C des Saarkarbons. Argumenta Palaeobotanica, 4: 1-11.

630 Remy, W., and Remy, R. 1977. Die Floren des Erdaltertums. Verlag Glückauf GmbH, 631 Essen.

632 Remy, W., and Remy, R. 1978. Beiträge zur Flora des Stefans und Autuns. Argumenta

633 Palaeobotanica, 5: 195-204.

634 Schultze, H.-P. 2009. Interpretation of marine and freshwater paleoenvironments in

635 Permo-Carboniferous deposits. Palaeogeography, Palaeoclimatology,

$636 \quad$ Palaeoecology, 281: 126-136.

637 Sellards, E.H. 1908. Fossil plants of the Upper Paleozoic of Kansas. Bulletin of the 638 University Geological Survey of Kansas, 9: 386-499.

639 Šimůnek, Z. 1996. Leaves and cuticles of the genus Lesleya Lesquereux from the Czech

640 Republic and from Illinois (USA). In Patterns in paleobotany: proceedings of a

641 Czech-U.S. Carboniferous paleobotany workshop, Springfield, Illinois. Edited by

642 R.L. Leary. Illinois State Museum Scientific Papers, 26, pp. 43-56. 
643 Taylor, T.N., Taylor, E.L., and Krings, M. 2009. Paleobotany. The biology and 644 evolution of fossil plants, second edition. Academic Press, San Diego, CA. 645 Tibert, N.E., Dewey, C.P., and Skema, V. 2011. Taxonomy and significance of the 646 nonmarine ostracoda from the Late Carboniferous and Early Permian Appalachian 647 Basin, United States. Micropaleontology, 57: 469-481.

648 van Hoof, T., Falcon-Lang, H.J., Hartkopf-Fröder, C., and Kerp, H. 2013. Conifer649 dominated palynofloras in the Middle Pennsylvanian strata of the De Lutte-6 650 borehole, The Netherlands: implications for evolution, palaeoecology and 651 biostratigraphy. Review of Palaeobotany and Palynology, 188: 18-37.

652 Wagner, R.H. 1983. The palaeogeographical and age relationships of the Portuguese 653 Carboniferous floras with those of other parts of the Western Iberian Peninsula. In 654 The Carboniferous of Portugal. Edited by M.J. Lemos de Sousa and J.T. Oliveira. 655 Memórias dos Serviços Geológicos de Portugal, Lisboa, Vol. 29, pp. 153-177. 656 Wagner, R.H. 1984. Megafloral Zones of the Carboniferous. In Neuvième Congrès 657 International de Stratigraphie et de Géologie du Carbonifère. Edited by P.K. 658 Sutherland and W.L. Manger. Illinois, Vol. 2, pp. 109-134.

659 Wagner, R.H. 2004. Climatic changes as mirrored by Carboniferous and Permian floral 660 distributions. Monografías del Jardín Botánico de Córdoba, 39: 29-39.

661 Wagner, R.H., and Lemos de Sousa, M.J. 1983. The Carboniferous Megafloras of 662 Portugal - A revision of identifications and discussion of stratigraphic ages. In The 663 Carboniferous of Portugal. Edited by M.J. Lemos de Sousa and J.T. Oliveira. 664 Memórias dos Serviços Geológicos de Portugal, Lisboa, Vol. 29, 127-152. 665 Wagner, R.H., and Álvarez-Vázquez, C. 2010. A redescription of the Stephanian 666 species Callipteridium virginianum (Fontaine \& White, 1880) comb. nov. and 
Wagner, R.H., Ribeiro, A., and Lemos de Sousa, M.J. 1984. Bacia Carbonífera do Douro. Reinterpretação da Geologia do sector Germunde-Choupelo. Recomendações para a investigação geológico-mineira deste sector e de sectores anexos, 17 pp. Formelo.

Zeiller, R. 1888. Études sur le terrain houiller de Commentry. In 2. Flore fossile I. Edited by B. Renault and R. Zeiller (1888-1890). Bulletin de la Societe de l'Industrie Minerale, 2 (2): 1-366.

Zeiller, R. 1890. Études des gîtes minérauc de la France - Bassin houiller et permien

678 Zeiller, R. 1900. Éléments de paléobotanique. Carré et Naud, Paris.

Zeiller, R. 1906. Bassin houiller et Permien de Blanzy et du Creusot. II. Flore fossile. Études Gîtes Minéraux de la France. Ministère des Travaux Publies, Paris.

Fig. 1. Map showing regional geological setting of the Upper Pennsylvanian (lower Gzhelian) Douro Carboniferous Basin in northwestern Portugal and the detailed geology and location of the Lesleya outcrop in the São Pedro da Cova region. Modified from Correia et al. (2013, fig. 1).

Fig. 2. (A) Generalized stratigraphic and sedimentologic column for the Douro units (TSU) recognized in the sequence (adapted from Pinto de Jesus 2001, fig. 1.3) and

690 the position of the Lesleya outcrop. Key for lithologies: a, breccias; b, conglomerates

691 and sandstones; c, siltstones and shales; d, coal beds. (B) Detailed stratigraphic and 
692 sedimentologic column for the Lesleya outcrop, in the São Pedro da Cova region, 693 showing positions of fossiliferous layers.

694 Fig. 3. Photographs of the Lesleya outcrop in the São Pedro da Cova region, 695 northwestern Portugal. (A) View of fossiliferous portion of outcrop, consisting of 696 siliciclastic deposits (mica-rich shale lithofacies) containing Lesleya and associated 697 flora (e.g., Cordaites) interlayered with pelitic deposits (clay-rich shale lithofacies) rich 698 in non-marine bivalves (Anthraconaia) and some insects. (B and C) Closer views of the 699 upper (B) and lower (C) parts of the fossiliferous sequence showing interlayered shale 700 and sandstone strata.

701 Fig. 4. Stratigraphic ranges and geographic distributions of Lesleya species in 702 Euramerica. Adapted from Šimůnek (1996, table 1). Abbreviations: Ca., Cantabrian; 703 Guadalup., Guadalupian; Gzheli., Gzhelian; Kasim., Kasimovian; M., Middle; Saxoni., 704 Saxonian; Serpukh., Serpukhovian; Stephan., Stephanian; Vi., Visean; WERS, Western 705 Europe Regional Scale; Zechst., Zechstein.

706 Fig. 5. Holotype leaf(UP-MHNFCP-094951/-094952/-094954) of Lesleya iberiensis sp.

707 nov., from the Late Pennsylvanian (early Gzhelian) of the Douro Carboniferous Basin,

708 Sao Pedro da Cova region, northwestern Portugal. (A) Photograph of original specimen,

709 preserved as a natural mold in grey shale, missing its tip, base, and a small piece

710 midway along leaf, and broken in three pieces. (B) Latex cast of original specimen,

711 showing positive relief. (C) Interpretive drawing of original specimen, showing

712 reconstructed leaf margins (dotted lines) based, in part, on paratypes and comparisons

713 with other congeners. Images at different magnifications; scale bars $=20 \mathrm{~mm}$.

714 Fig. 6. Paratype leaves of Lesleya iberiensis sp. nov., from the Late Pennsylvanian

715 (early Gzhelian) of the Douro Carboniferous Basin, Sao Pedro da Cova region, 
716 northwestern Portugal. All are photographs of uncoated, original specimens preserved 717 as natural molds in grey shale. (A and B) Paratype ZS 507, lower part of leaf; part (A) 718 and counterpart (B) slabs. (C) Paratype ZS 510, nearly complete, but poorly preserved 719 leaf. (D) Paratype ZS 508, lower part of leaf. Images at different magnifications; scale 720 bars $=20 \mathrm{~mm}$.

721 Fig. 7. Proposed interpretive model of the living habitat of Lesleya and associated flora 722 in riparian environments during the Late Pennsylvanian within the intramontane basin 723 Douro Carboniferous Basin, Variscan orogen, northwestern Portugal. Adapted from 724 Pinto de Jesus (2001) and Einsele (1992). Abbreviations: DCB, Douro Carboniferous 725 Basin; DBT, Douro-Beiras Carboniferous Trough. No vertical or lateral scales implied.

\section{Table caption}

727 Table 1. Comparison of leaf features among Lesleya iberiensis sp. nov. and the other 11

728 named species in the genus. Data compiled from descriptions and figures in papers cited 729 in "Authors" column. 


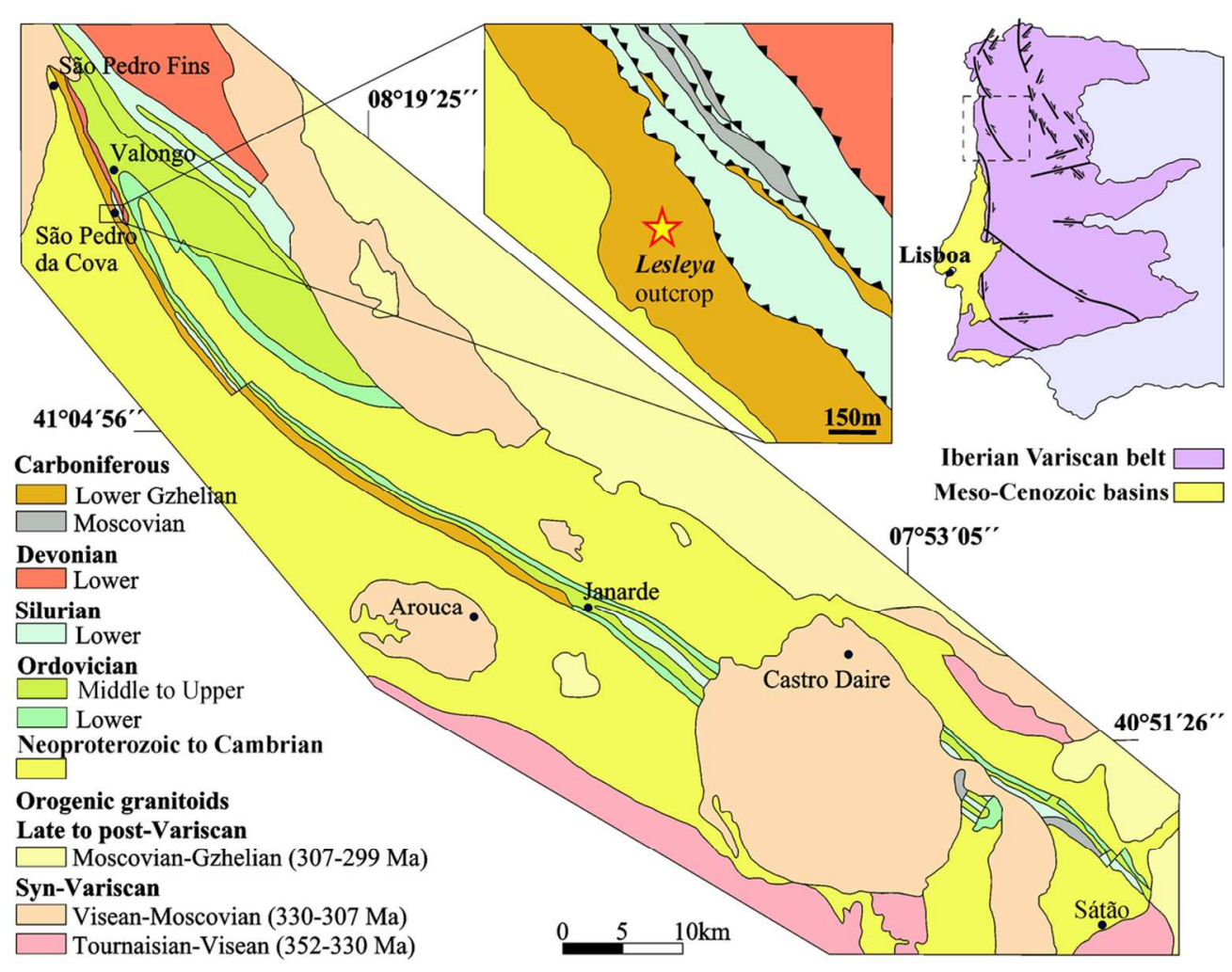

Fig. 1. Map showing regional geological setting of the Upper Pennsylvanian (lower Gzhelian) Douro Carboniferous Basin in northwestern Portugal and the detailed geology and location of the Lesleya outcrop in the São Pedro da Cova region. Modified from Correia et al. (2013, fig. 1). $107 \times 83 \mathrm{~mm}(300 \times 300$ DPI $)$ 


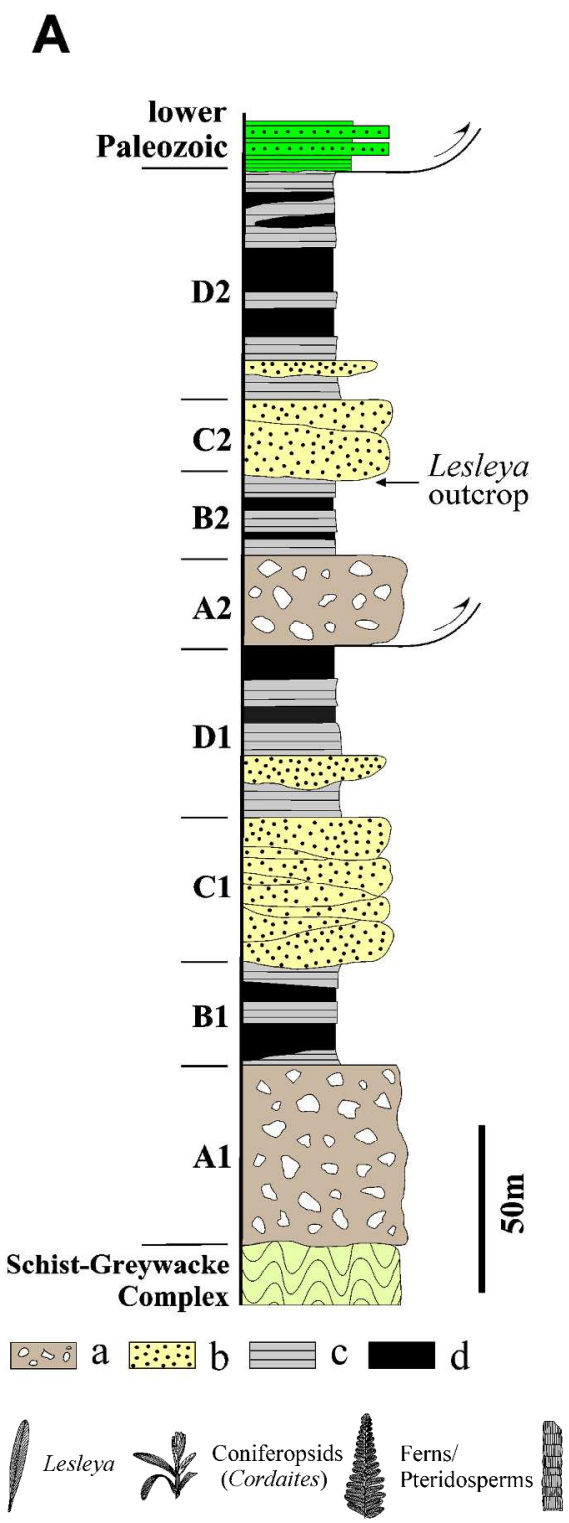

B

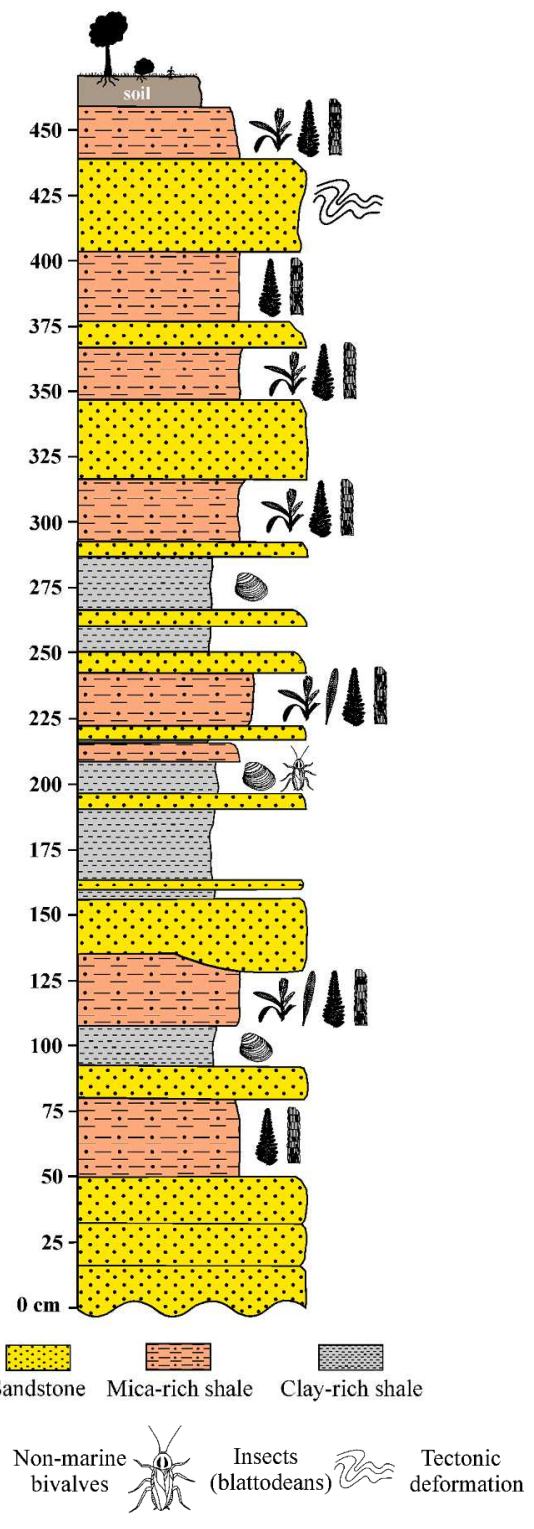

Fig. 2. (A) Generalized stratigraphic and sedimentologic column for the Douro Carboniferous Basin, northwestern Portugal, showing the eight tectono-sedimentary units (TSU) recognized in the sequence (adapted from Pinto de Jesus 2001, fig. 1.3) and the position of the Lesleya outcrop. Key for lithologies: a, breccias; b, conglomerates and sandstones; $c$, siltstones and shales; d, coal beds. (B) Detailed stratigraphic and sedimentological column for the Lesleya outcrop, in the São Pedro da Cova region, showing positions of fossiliferous layers.

$196 \times 232 \mathrm{~mm}(300 \times 300 \mathrm{DPI})$ 

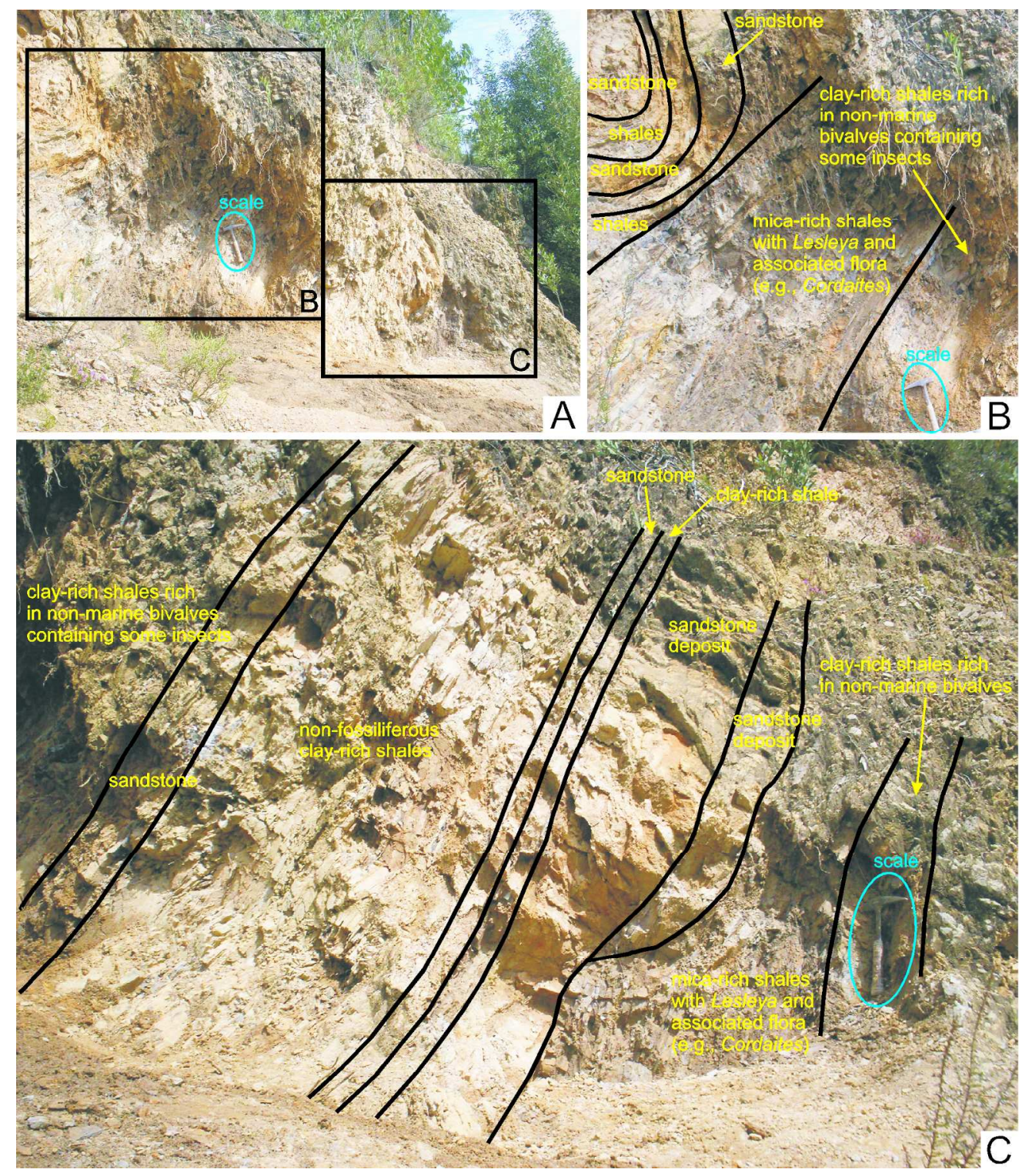

Fig. 3. Photographs of the Lesleya outcrop in the São Pedro da Cova region, northwestern Portugal. (A) View of fossiliferous portion of outcrop, consisting of siliciclastic deposits (mica-rich shale lithofacies) containing Lesleya and associated flora (e.g., Cordaites) interlayered with pelitic deposits (clay-rich shale lithofacies) rich in non-marine bivalves (Anthraconaia) and some insects. ( $B$ and $C$ ) Closer views of the upper (B) and lower (C) parts of the fossiliferous sequence showing interlayered shale and sandstone strata. $183 \times 212 \mathrm{~mm}(300 \times 300 \mathrm{DPI})$ 


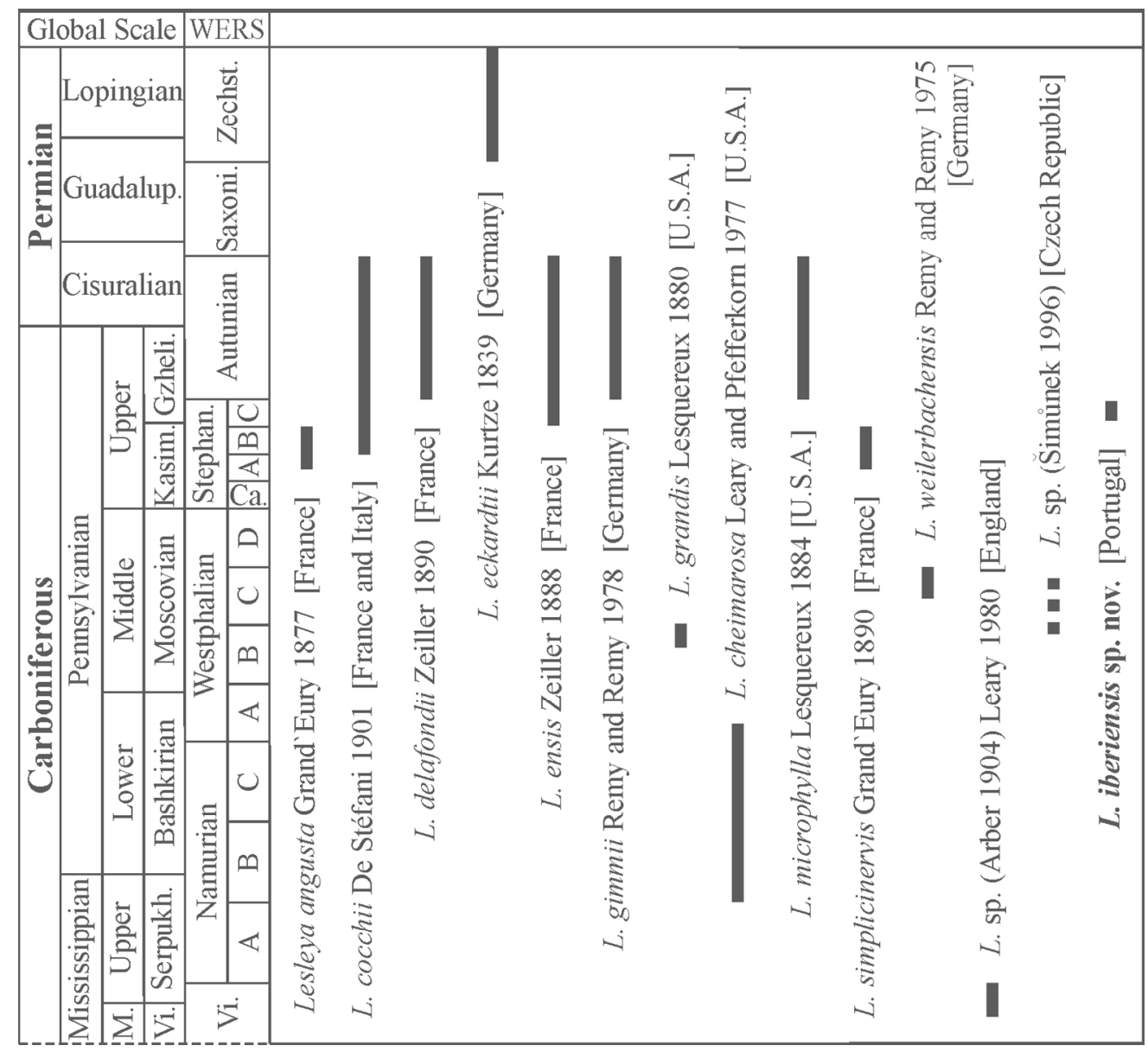

Fig. 4. Stratigraphic ranges and geographic distributions of Lesleya species in Euramerica. Adapted from Šimůnek (1996, table 1). Abbreviations: Ca., Cantabrian; Guadalup., Guadalupian; Gzheli., Gzhelian; Kasim., Kasimovian; M., Middle; Saxoni., Saxonian; Serpukh., Serpukhovian; Stephan., Stephanian; Vi., Visean; WERS, Western Europe Regional Scale; Zechst., Zechstein. $135 \times 124 \mathrm{~mm}(300 \times 300$ DPI $)$ 

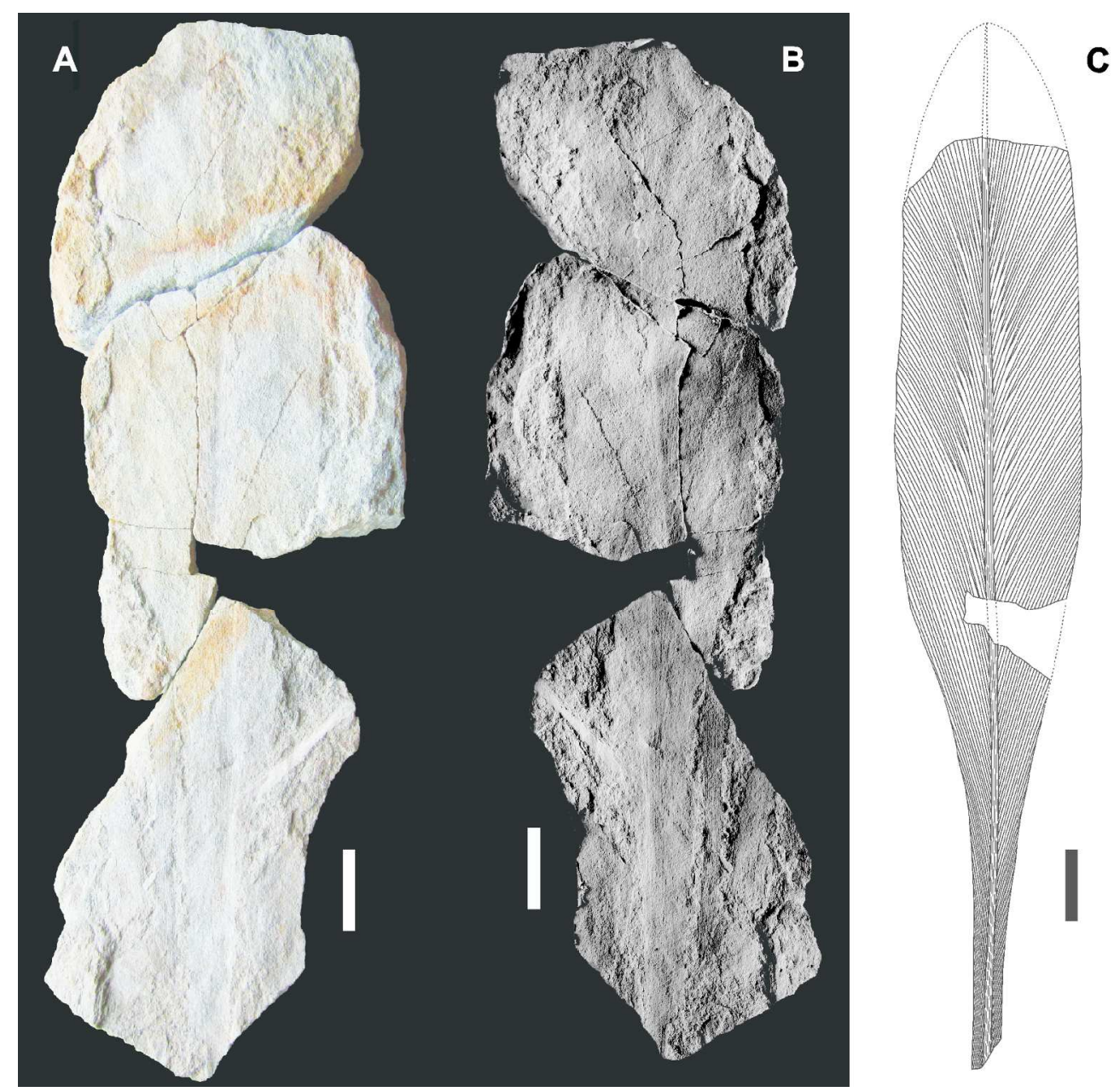

Fig. 5. Holotype leaf (UP-MHNFCP-094951/-094952/-094954) of Lesleya iberiensis sp. nov., from the Late Pennsylvanian (early Gzhelian) of the Douro Carboniferous Basin, Sao Pedro da Cova region, northwestern Portugal. (A) Photograph of original specimen, preserved as a natural mold in grey shale, missing its tip, base, and a small piece midway along leaf, and broken in three pieces. (B) Latex cast of original specimen, showing positive relief. (C) Interpretive drawing of original specimen, showing reconstructed leaf margins

(dotted lines) based, in part, on paratypes and comparisons with other congeners. Images at different magnifications; scale bars $=20 \mathrm{~mm}$. $184 \times 178 \mathrm{~mm}(299 \times 299 \mathrm{DPI})$ 


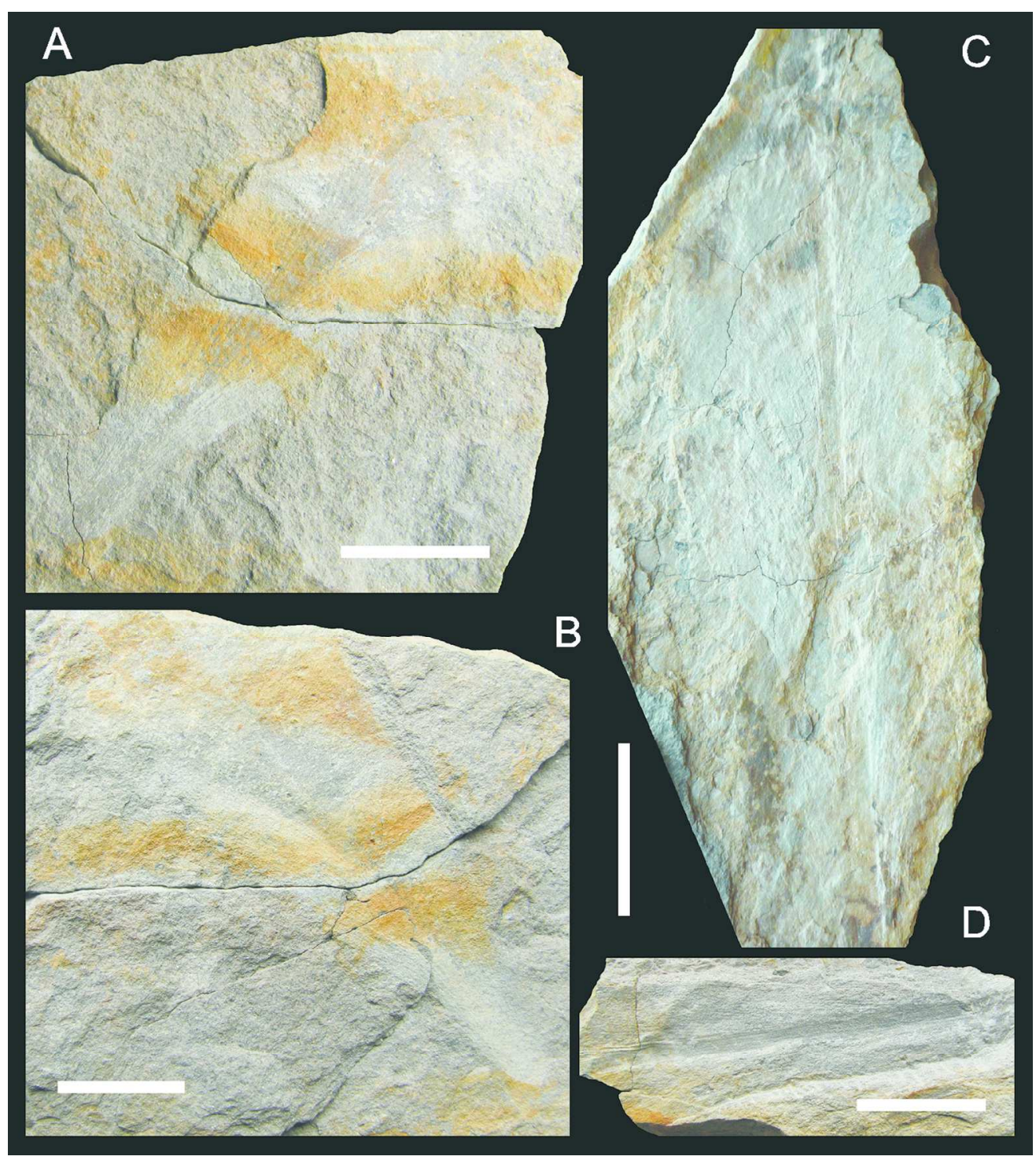

Fig. 6. Paratype leaves of Lesleya iberiensis sp. nov., from the Late Pennsylvanian (early Gzhelian) of the Douro Carboniferous Basin, Sao Pedro da Cova region, northwestern Portugal. All are photographs of uncoated, original specimens preserved as natural molds in grey shale. (A and B) Paratype ZS 507, lower part of leaf; part (A) and counterpart (B) slabs. (C) Paratype ZS 510, nearly complete, but poorly preserved leaf. (D) Paratype ZS 508, lower part of leaf. Images at different magnifications; scale bars $=20 \mathrm{~mm}$. $134 \times 150 \mathrm{~mm}(300 \times 300 \mathrm{DPI})$ 


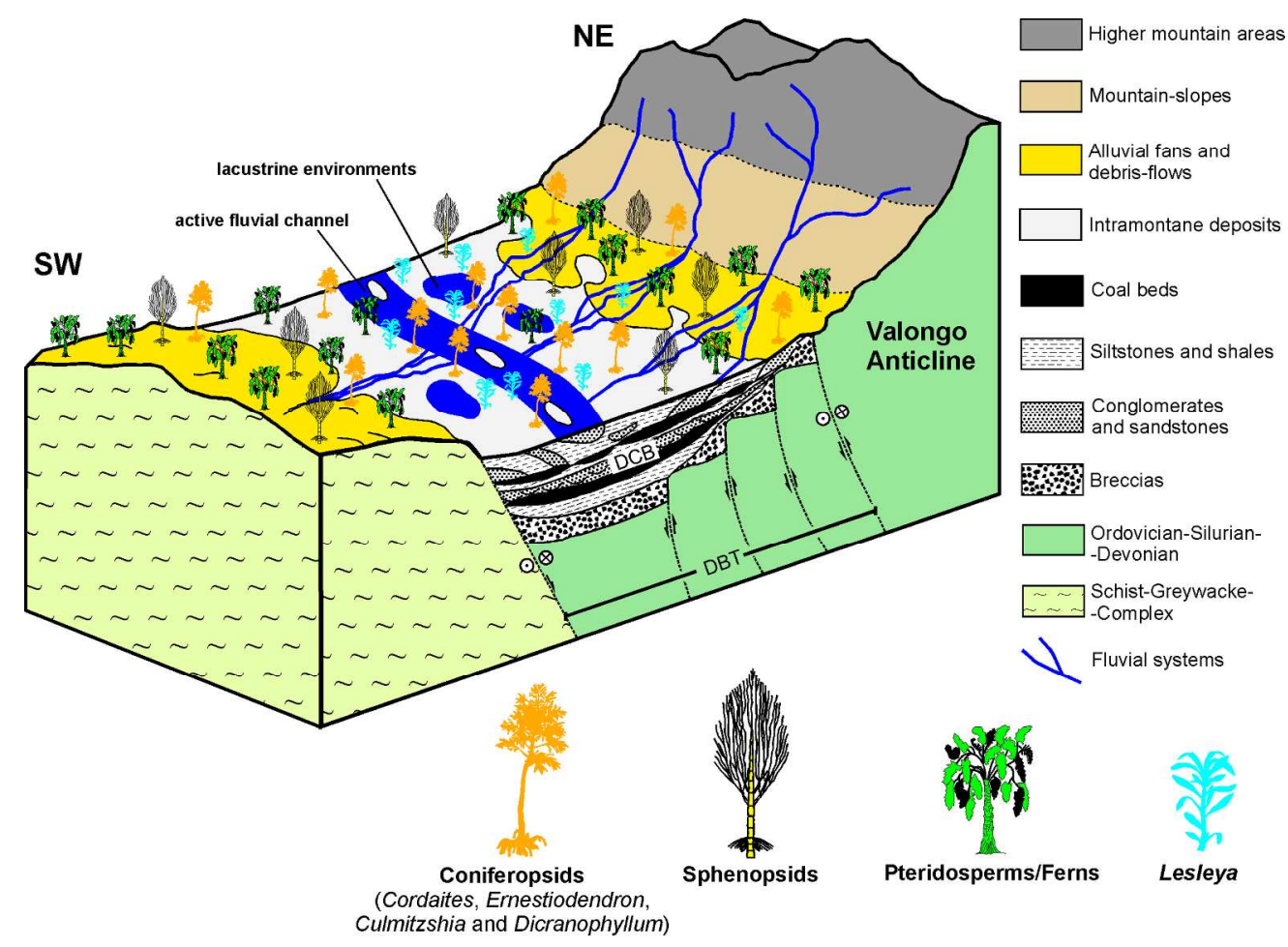

Fig. 7. Proposed interpretive model of the living habitat of Lesleya and associated flora in riparian environments during the Late Pennsylvanian within the intramontane basin Douro Carboniferous Basin, Variscan orogen, northwestern Portugal. Adapted from Pinto de Jesus (2001) and Einsele (1992). Abbreviations: DCB, Douro Carboniferous Basin; DBT, Douro-Beiras Carboniferous Trough. No vertical or lateral scales implied.

$205 \times 149 \mathrm{~mm}(300 \times 300 \mathrm{DPI})$ 


$\begin{array}{lllrr}\text { Lesleya species } & \text { Authors } & \text { Pinna (leaf shape) } & \text { Width [mm] } & \text { Length [mm] } \\ \text { delafondi } & \text { Zeiller 1890 } & \text { lanceolate } & 70 & >200 \\ \text { grandis } & \text { Lesquereux 1880 } & \text { lanceolate } & 80 & 200 \\ \text { cheimarosa } & \text { Leary and Pfefferkorn 1977 } & \text { lanceolate } & 40 & 200 \\ \text { angusta } & \text { Grand Eury 1877 } & \text { lanceolate } & 17 & 170 \\ \text { cocchii } * & \text { De Stéfani 1901 } & \text { ?lanceolate } & 16 & ? \\ \text { ensis } & \text { Zeiller 1888 } & \text { lanceolate } & 40 & >115 \\ \text { gimmii } & \text { Remy and Remy 1978 } & \text { narrow-elliptical } & 30-40 & >200 \\ \text { microphylla** } & \text { Lesquereux 1884 } & \text { oval-oblong } & 16 & 40 \\ \text { simplicinervis } & \text { Grand'Eury 1890 } & \text { ?spatulate } & 27 & 110 \\ \text { weilerbachensis } & \text { Remy and Remy 1975 } & \text { lanceolate } & 65 & >250 \\ \text { eckardtii*** } & \text { Kurtze 1839 } & \text { lanceolate } & 23-30 & >200 \\ \text { iberiensis sp. nov. } & \text { in this paper } & \text { lanceolate } & 50 & >\mathbf{2 2 5}\end{array}$

*According Zeiller (1906);

**According to the description;

***This species still be assigned to genus Taeniopteris Brongniart by some authors - Taeniopteris eck

\begin{tabular}{|c|c|c|c|c|c|c|c|c|c|c|c|c|}
\hline Lesleya species & Authors & $\begin{array}{c}\text { Pinna } \\
\text { (leaf shape) }\end{array}$ & $\begin{array}{l}\text { Width } \\
{[\mathrm{mm}]}\end{array}$ & $\begin{array}{l}\text { Length } \\
\text { [mm] }\end{array}$ & Leaf base & Leaf apex & $\begin{array}{c}\text { Midvein } \\
\text { width [mm] }\end{array}$ & $\begin{array}{c}\text { Margin } \\
\text { shape }\end{array}$ & Venation & $\begin{array}{l}N^{\circ} \text { bifurcations } \\
\text { of lateral veins }\end{array}$ & $\begin{array}{c}\text { Angle between } \\
\text { lateral vein/ } \\
\text { margin }\end{array}$ & $\begin{array}{r}\text { Angle betv } \\
\text { lateral vi } \\
\text { midvei }\end{array}$ \\
\hline delafondii & Zeiller 1890 & lanceolate & 70 & $>200$ & ? & obtuse & ? & $\begin{array}{c}\text { denticulate? } \\
\text { to entire }\end{array}$ & slightly curved & $3-24$ & $30^{\circ}-32^{\circ}$ & $26^{\circ}$ \\
\hline grandis & Lesquereux 1880 & lanceolate & 80 & 220 & ?cuneate & obtuse & strong & $\begin{array}{c}\text { entire to } \\
\text { lobate/lancerate }\end{array}$ & $\begin{array}{c}\text { some sinusoidal } \\
\text { effect }\end{array}$ & 3-4 & $20^{\circ}-82^{\circ}$ & $56^{\circ}-60^{\circ}$ \\
\hline cheimarosa & $\begin{array}{c}\text { Leary and } \\
\text { Pfefferkorn } 1977 \\
\end{array}$ & lanceolate & 40 & 200 & $\begin{array}{c}\text { long and } \\
\text { narrow (cuneate) }\end{array}$ & $\begin{array}{c}\text { sub/lanceolate } \\
\text { to accute }\end{array}$ & broad 0.7-2 & entire & $\begin{array}{c}\text { S-shaped } \\
\text { (sinuous) }\end{array}$ & $1-2$ & $40^{\circ}-70^{\circ}$ & $10^{\circ}-70^{\circ}$ \\
\hline angusta & Grand'Eury 1877 & lanceolate & 17 & 170 & obtuse & blunt & ? & entire & $\begin{array}{l}\text { slighty curved } \\
\text { to margin }\end{array}$ & $0-1$ & $45^{\circ}-55^{\circ}$ & $\pm 35^{\circ}$ \\
\hline${\text { cocchi }{ }^{*}}^{*}$ & De Stéfani 1901 & ?lanceolate & 16 & $?$ & $?$ & $?$ & 2 & entire & curved to margin & $\begin{array}{c}1-2 \\
\text { near base } \\
\end{array}$ & $\pm 50^{\circ}$ & $\pm 15^{\circ}$ \\
\hline ensis & Zeiller 1888 & lanceolate & 40 & $>115$ & ? & ?blunt & 1 & entire & slighty curved & $2-3$ & $35^{\circ}-40^{\circ}$ & $10^{\circ}-12^{\circ}$ \\
\hline gimmii & Remy and Remy 1978 & $\begin{array}{l}\text { nalrow- } \\
\text { elliptical }\end{array}$ & $30-40$ & $>200$ & acute & ? & $\begin{array}{c}6 \\
\text { at base }\end{array}$ & entire & slightly S-shaped & $2-3$ & $28^{\circ}-53^{\circ}$ & $06^{\circ}$ \\
\hline microphylla** & Lesquereux 1884 & oval-oblong & 16 & 40 & $\begin{array}{l}\text { decurrent, } \\
\text { shortly auriculate }\end{array}$ & obtuse & $?$ & entire & $?$ & $?$ & $50^{\circ}$ & very acut \\
\hline simplicinervis & Grand'Eury 1890 & ?spatulate & 27 & 110 & rounded & rounded & ? & entire & $\begin{array}{l}\text { slighty curved } \\
\text { to margin }\end{array}$ & $\begin{array}{c}0 \\
\text { (simple veins) }\end{array}$ & $\pm 35^{\circ}$ & $15^{\circ}-20^{\circ}$ \\
\hline weilerbachensis & Remy and Remy 1975 & lanceolate & 65 & $>250$ & cuneate & acute & $1.5-2$ & dentate & slighty curved & $3-? 4$ & $09^{\circ}-10^{\circ}$ & $13^{\circ}-14^{\circ}$ \\
\hline eckardtii *** & Kurtze 1839 & lanceolate & $23-30$ & $>200$ & acute & blunt & 2 & $\begin{array}{l}\text { entire to } \\
\text { ?lobate }\end{array}$ & straight & $\begin{array}{c}0 \\
\text { (simple veins) }\end{array}$ & $\pm 60^{\circ}$ & $60^{\circ}$ \\
\hline iberiensis sp. nov. & in this paper & lanceolate & 50 & $>225$, & $\begin{array}{c}\text { long and } \\
\text { narrow (cuneate) }\end{array}$ & ?lanceolate & broad 1-3 & entire & $\begin{array}{c}\text { slighty curved } \\
\text { (arched) }\end{array}$ & $1-2$ & $05^{\circ}-35^{\circ}$ & $07^{\circ}-15^{\circ}$ \\
\hline $\begin{array}{l}\text { *According Zeiller } \\
\text { **According to the } \\
\text { ****This species still }\end{array}$ & $\begin{array}{l}\text { (1906); } \\
\text { description; } \\
1 \text { be assigned to genus }\end{array}$ & TaeniopteBisongr & niart by sol & ome authors & Taeniopteri & is eckakdurzze 18 & 39 (see Halle 20 & 14). & & & & \\
\hline
\end{tabular}




\begin{tabular}{|c|c|c|}
\hline Leaf base & Leaf apex & Midvein width [mm] \\
\hline$?$ & obtuse & $?$ \\
\hline ?cuneate & obtuse & strong \\
\hline long and narrow (cuneate) & sub/lanceolate to acute & broad 0.7-2 \\
\hline obtuse & blunt & ? \\
\hline$?$ & $?$ & 2 \\
\hline$?$ & ?blunt & 1 \\
\hline acute & $?$ & 6 at base \\
\hline decurrent, shortly auriculate & obtuse & $?$ \\
\hline rounded & rounded & $?$ \\
\hline cuneate & acute & $1.5-2$ \\
\hline acute & blunt & 2 \\
\hline long and narrow (cuneate) & ?lanceolate & broad 1-3 \\
\hline
\end{tabular}

ardtii Kurtze 1839 (see Halle 2014).

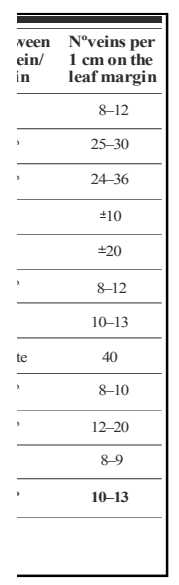




$\begin{array}{clc}\text { Margin shape } & \text { Venation } & \text { No bifurcations of lateral veins } \\ \text { denticulate? to entire } & \text { slightly curved } & 3-? 4 \\ \text { entire to lobate/lanceolate } & \text { some sinusoidal effect } & 3-4 \\ \text { entire } & \text { S-shaped (sinuous) } & 1-2 \\ \text { entire } & \text { slightly curved to margin } & 0-1 \\ \text { entire } & \text { curved to margin } & 1-2 \text { near base } \\ \text { entire } & \text { slightly curved } & 2-3 \\ \text { entire } & \text { slightly S-shaped } & 2-3 \\ \text { entire } & \text { ? } & \text { ? } \\ \text { entire } & \text { slightly curved to margin } & 0 \text { (simple veins? } \\ \text { dentate } & \text { slightly curved } & 3-? 4 \\ \text { entire to ?lobate } & \text { straight } & 0 \text { (simple veins) } \\ \text { entire } & \text { slightly curved (arched) } & \mathbf{1 - 2}\end{array}$




\begin{tabular}{|c|c|}
\hline Angle between lateral vein/margin & Angle between lateral vein/midvein \\
\hline $30^{\circ}-32^{\circ}$ & $26^{\circ}$ \\
\hline $20^{\circ}-82^{\circ}$ & $56^{\circ}-60^{\circ}$ \\
\hline $40^{\circ}-70^{\circ}$ & $10^{\circ}-70^{\circ}$ \\
\hline $45^{\circ}-55^{\circ}$ & $\pm 35^{\circ}$ \\
\hline $\pm 50^{\circ}$ & $\pm 15^{\circ}$ \\
\hline $35^{\circ}-40^{\circ}$ & $10^{\circ}-12^{\circ}$ \\
\hline $28^{\circ}-53^{\circ}$ & $06^{\circ}$ \\
\hline $50^{\circ}$ & very acute \\
\hline $\pm 35^{\circ}$ & $15^{\circ}-20^{\circ}$ \\
\hline $09^{\circ}-10^{\circ}$ & $13^{\circ}-14^{\circ}$ \\
\hline $\pm 60^{\circ}$ & $60^{\circ}$ \\
\hline $05^{\circ}-35^{\circ}$ & $07^{\circ}-15^{\circ}$ \\
\hline
\end{tabular}




№ veins per $1 \mathrm{~cm}$ on the leaf margin
$8-12$
$25-30$
$24-36$
\pm 10
\pm 20
$8-12$
$10-13$
$8-10$
$12-20$
$8-9$
$10-13$

https://mc06.manuscriptcentral.com/cjes-pubs 